\title{
Apical Seal of Root Canals with Gutta-Percha Points with Calcium Hydroxide
}

\author{
Roberto HOLLAND ${ }^{1}$ \\ Sueli Satomi MURATA ${ }^{2}$ \\ Henrian Gonzaga BARBOSA ${ }^{1}$ \\ Osvaldo GARLIPP ${ }^{1}$ \\ Valdir de SOUZA ${ }^{1}$ \\ Eloi DEZAN JUNIOR ${ }^{1}$ \\ ${ }^{1}$ Discipline of Endodontics, Department of Restorative Dentistry \\ ${ }^{2}$ Department of Pediatric and Social Dentistry \\ Faculty of Dentistry of Araçatuba, UNESP, Araçatuba, SP, Brazil
}

\begin{abstract}
The objective of this research was to determine if gutta-percha points with calcium hydroxide $\left[\mathrm{Ca}(\mathrm{OH})_{2}\right]$ improve the apical seal after root canal filling and if the master point does it alone. Human single recently extracted teeth were biomechanically prepared and the root canals filled by the lateral condensation technique with ZOE and gutta-percha points, with or without calcium hydroxide. The teeth were placed into a $2 \%$ methylene blue solution in a vacuum environment for $24 \mathrm{~h}$ after which they were processed for stereomicroscope evaluation. Better results were observed with the teeth filled with gutta-percha points with calcium hydroxide ( $\mathrm{p}=0.01$ ). We conclude that these new points make a better apical seal and that these results can also be obtained with the calcium hydroxide master point associated with regular ones $(\mathrm{p}=0.05)$.
\end{abstract}

Key Words: calcium hydroxide, gutta-percha points, apical leakage.

\section{INTRODUCTION}

The root canal must be hermetically filled in order to hinder the communication of its interior with periapical tissues. Many studies have been developed with the object of studying the factors that could influence the sealing property of root canal fillings. It has been demonstrated that the sealing efficiency is affected by the filling technique $(1,2)$, the type of sealer (3), as well as the clinical procedures done before root canal filling (4). Other factors can modify the sealing property of root canal fillings, i.e., EDTA, camphorated p-monochlorophenol and a corticosteroid-antibiotic solution. It has been reported that remnants of these drugs can significantly decrease leakage after root canal filling (5).

Calcium hydroxide has been employed as a dressing in cases of tooth reimplantation (6), treatment of teeth with open apices $(7,8)$, treatment of teeth with periapical lesions (9) and, more recently, as a routine dressing during root canal treatment (10). It has been reported that after use of some substances it is possible to observe their remnants in the root canal walls even after exhaustive attempts to remove them (11). For this motive, the presence of calcium hydroxide residue was investigated with the objective of evaluating if they modify the quality of the root canal filling (12). It has been reported that after use of a calcium hydroxide dressing, there is less leakage in root canal fillings with different sealers $(5,13,14)$. This was also observed when this medication was employed as an apical plug (15).

These observations about the effect of calcium hydroxide on the amount of leakage stimulated the study of an experimental gutta-percha point with calcium hydroxide (Dentsply) in its formulation. Less leakage in root canal fillings with calcium hydroxide gutta-percha points than with regular points has been 
reported (16). However, Dentsply later altered the formulation of the gutta-percha points to comply with the new ISO specifications (ISO 6877). This modification decreased the amount of calcium hydroxide in the experimental gutta-percha points.

Thus, the subject of this paper is to observe if the modification in the amount of calcium hydroxide in the gutta-percha formulation has an influence on leakage after root canal filling with this type of point.

\section{MATERIAL AND METHODS}

Fifty single-rooted human teeth, recently extracted, were employed in this experiment. The coronal portion of the teeth was sectioned and the root canals were prepared biomechanically $1 \mathrm{~mm}$ short of the apical foramen up to a size $40 \mathrm{~K}$ file, before step-back instrumentation up to a $\# 80 \mathrm{H}$ file. During instrumentation, abundant and frequent irrigation with $1 \%$ sodium hypochlorite was done.

After biomechanical preparation, all roots were coated with a layer of Araldite (Brascola Ltda., São Bernardo do Campo, SP, Brazil), except for the area surrounding the apical foramen and the coronal opening. The root canals were then filled by the lateral condensation technique with zinc oxide eugenol sealer (ZOE; S.S. White, Artigos Dentários Ltda, Rio de Janeiro, RJ, Brazil) and gutta-percha points containing or not containing calcium hydroxide in their formula- tion (Dentsply Industria e Comércio Ltda, Rio de Janeiro, RJ, Brazil).

Three experimental groups were constituted according to the type of gutta-percha points used: group I - root canals filled by the lateral condensation technique with ZOE sealer and regular gutta-percha points; group II - root canals filled by the lateral condensation technique with ZOE sealer and the main and auxiliary gutta-percha points with calcium hydroxide; group III root canals filled by the lateral condensation technique with ZOE sealer and a calcium hydroxide main guttapercha point and regular auxiliary gutta-percha points. Positive and negative control groups were also constituted. Some root canals were filled and all the roots were coated with Araldite (negative control). The positive control was constituted by root canals not filled. The 3 experimental groups and the 2 control groups were formed by 10 roots each. The coronal portion of the root canals of groups I, II and III was sealed with Araldite after filling. The apical portion of the roots of these 3 groups was immersed in water for $24 \mathrm{~h}$ to permit the hardening of the filling material and of Araldite in the coronal portion.

All specimens were then fully immersed into a $2 \%$ methylene blue solution $(\mathrm{pH} 7.0)$ inside a flask which was attached to a vacuum pump providing a vacuum of $0.002 \mathrm{mmHg}$ for $15 \mathrm{~min}$. Twenty-four hours later the teeth were washed, dried and grooved in a buccolingual direction without penetrating the root

Table 1. Linear marginal leakage, in millimeters, observed in the specimens in the experimental groups.

\begin{tabular}{|c|c|c|c|c|c|c|c|c|c|c|c|}
\hline \multirow[t]{2}{*}{ Groups } & \multicolumn{11}{|c|}{ Specimens } \\
\hline & 1 & 2 & 3 & 4 & 5 & 6 & 7 & 8 & 9 & 10 & Mean \pm SD \\
\hline Regular points & 2.50 & 2.10 & 2.24 & 2.18 & 2.80 & 3.00 & 2.58 & 3.00 & 3.60 & 2.12 & $2.61 \pm 0.49^{*}$ \\
\hline $\begin{array}{l}\text { Main and } \\
\text { auxiliary points } \\
\text { with } \mathrm{Ca}(\mathrm{OH})_{2}\end{array}$ & 0.60 & 1.20 & 1.08 & 1.42 & 1.00 & 0.92 & 0.70 & 0.60 & 1.08 & 0.60 & $0.92 \pm 0.29^{\mathrm{n}}$ \\
\hline $\begin{array}{l}\text { Main points } \\
\text { with } \mathrm{Ca}(\mathrm{OH})_{2} \text { and } \\
\text { regular auxiliary poin }\end{array}$ & 1.00 & 0.80 & 0.80 & 1.00 & 1.20 & 1.20 & 1.04 & 1.28 & 0.80 & 1.08 & $1.02 \pm 0.18^{\mathrm{ns}}$ \\
\hline
\end{tabular}

$* \mathrm{p}=0.01$, statistically different from other groups.

${ }^{\mathrm{ns}} \mathrm{p}>0.05$, not statistically different. 
canal. A chisel was placed in the groove to split the root in half with gentle pressure. The filling material was removed and the greatest extent of linear dye penetration was recorded using a stereomicroscope with a graded eyepiece.

\section{RESULTS}

The positive control showed total leakage in all specimens and the negative control did not show leakage. The data for the 3 experimental groups (Table 1) were submitted to analysis of variance and the Tukey test, which showed that the use of calcium hydroxide gutta-percha points, and the main gutta-percha point with calcium hydroxide and regular auxiliary points provided significantly better sealing than with the regular main and auxiliary points $(\mathrm{p}=0.01)$. There was no statistically significant difference between the leakage when calcium hydroxide points or only the main calcium hydroxide point with regular auxiliary points were used $(p>0.05)$.

\section{DISCUSSION}

In a previous experiment, it was reported that root canal filling with gutta-percha points containing calcium hydroxide exhibited less leakage than root canal filling with regular points (16). However, the formulation of the studied gutta-percha points was modified to comply with ISO specifications. In the present experiment, we observed that the decrease in the amount of calcium hydroxide in these points (Dentsply) did not alter the leakage previously observed. We also noted that the use of only the master point with calcium hydroxide gave almost the same results when both kinds of calcium hydroxide points were employed.

It is of interest to consider that calcium hydroxide on the external surface of the points, in contact with air, is gradually converted into calcium carbonate, which does not have the same properties of calcium hydroxide. However, calcium hydroxide located in the interior of the points may be protected from this alteration. Theoretically, the modified points would not have the same properties as the original points. Nevertheless, during lateral condensation, the calcium hydroxide located in the interior of the points could be released and thus converted into calcium carbonate $(16,18)$.
Another question is what type of sealer would have leakage altered by contact with calcium hydroxide. It was reported that calcium hydroxide gutta-percha points improved leakage qualities of zinc oxide-eugenol sealers, Endomethasone and Grossman cement (16). When an intracanal calcium hydroxide dressing is employed it is possible to observe less leakage with the sealers AH 26, Fill Canal and Tubli Seal (13-15,17), but we do not know if the same will occur with the guttapercha points containing this substance.

Various hypotheses have tried to explain the mechanism action of this drug when less leakage is observed $(14,15)$. In the case of gutta-percha points, it is possible that an expansion of the sealer could occur when in contact with the alkaline $\mathrm{pH}$ of the points (16).

Another detail to be considered is the radiopacity of these points. For gutta-percha points, the ISO specification established a minimum radiopacity 6 times greater than that of aluminum. According to the manufacturer, the points we studied have a radiopacity 7 times greater than aluminum, however, they are less radiopaque than regular points.

In relation to the reported properties of the points it is necessary to consider that every procedure that improves the sealing quality is of interest if it does not harm its biological properties. Some researchers believe that it is difficult to evaluate the biological significance of major or minor dye leakage (19). The molecular weight of the bacterial endotoxin is greater than that of methylene blue (20). When it is evaluated directly, the leakage of endotoxin is less than the minor leakage of methylene blue (19). Thus, the real influence of the apical leakage on the healing process after root canal treatment must be better analyzed.

\section{RESUMO}

Foi propósito deste trabalho observar se o uso de cones de gutapercha contendo $\mathrm{Ca}(\mathrm{OH})_{2}$, promove melhora no selamento marginal apical e, também, se apenas o cone principal contendo essa droga produz esse efeito. Assim, dentes humanos extraídos foram preparados biomecânicamente e obturados pela técnica da condensação lateral com OZE e cones de guta-percha contendo ou não $\mathrm{Ca}(\mathrm{OH})_{2}$. Após imersão dos espécimes em azul de metileno a $2 \%$, em ambiente com vácuo, observou-se diferença estatisticamente significante entre os espécimes obturados com cones contendo $\mathrm{Ca}(\mathrm{OH})_{2}$, comparativamente aos casos obturados com cones de guta percha comuns $(\mathrm{p}=0.01)$. Os resultados obtidos permitiram concluir que esses cones tornam as obturações mais herméticas e que esse efeito também pode ser obtido com o emprego do cone principal da mesma fórmula, aliado a cones acessórios comuns ( $\mathrm{p}=0.05)$. 


\section{REFERENCES}

1. Holland R, Souza V, Abdalla T, Russo MC. Sealing properties of some root filling materials evaluated with radioisotope. Aust Dent J 1974;19:322-325.

2. Holland R, Souza V, Pannain R, Nery MJ, Mello W, Bernabé PFE. Avaliação da eficiência do selamento marginal de obturações de canal. Influência de variáveis introduzidas no método da condensação lateral. RGO 1975;23:247-253.

3. Holland R, Crivelini MM, Zampieri Jr M, Souza V, Saliba O. Qualidade do selamento marginal obtido com diferentes cimentos à base de hidróxido de cálcio. Rev Paul Odont 1991;13:27-35.

4. Holland R, Zampieri Jr M, Souza V, Saliba O. Influência de alguns procedimentos clínicos na infiltração marginal de obturações realizadas pela técnica da condensação lateral. Rev Paul Odont 1991;13:29-38.

5. Holland R, Paula EC, Pereira ALS, Souza V, Saliba O. Infiltração marginal dos cimentos endodônticos. RGO 1991;39:413-416.

6. Moro MC, Souza V, Okamoto T, Holland R. Reimplantes intencionais imediatos: influência dos curativos de calcitonina e de hidróxido de cálcio e obturação dos canais radiculares com cimento Sealapex. BCI 2002;9:51-57.

7. Heithersay GS. Stimulation of root formation in incompletely developed pulpless teeth. Oral Surg Oral Med Oral Pathol 1970;29:620-630.

8. Holland R, Souza V, Tagliavini RL, Milanezi LA. Healing process of teeth with open apices: histological study. Bull Tokyo Dent Coll 1971;12:333-338.

9. Heithersay GS. Calcium hydroxide in the treatment of pulpless teeth with associated pathology. J Brit Endod Soc 1975;8:74-93.

10. Bystrom A, Claesson R, Sundqvist G. The antibacterial effect of camphorated parachlorophenol, camphorated phenol and calcium hydroxide in the treatment of infected root canals. Endod Dent Traumatol 1985;1:170-175.

11. Zurbriggen T, DelRio CE, Brady JM. Postdebridement retention of endodontic reagents: a quantitative measurement with radioactive isotope. J Endodon 1975;1:298-299.

12. Foster KH. Removal of $\mathrm{Ca}(\mathrm{OH})_{2}$ from the root canal. J Endodon 1991;17:187(Abstract).

13. Holland R, Murata SS. Efeito do hidróxido de cálcio como curativo de demora no selamento marginal após a obturação de canal. Rev Assoc Paul Cir Dent 1993;47:1203-1207.

14. Porkaew P, Retief H, Barfield RD, Lacefield WR, Soong SJ. Effects of calcium hydroxide paste as an intracanal medicament on apical seal. J Endodon 1990;16:369-374.

15. Weisenseel JA, Hicks ML, Peller Jr GB. Calcium hydroxide as an apical barrier. J Endodon 1987;13:1-5.

16. Holland R, Murata SS, Dezan Jr E, Garlipp O. Apical leakage after root canal filling with an experimental calcium hydroxide gutta-percha point. J Endodon 1996;22:71-73.

17. Holland R, Murata SS, Kissimoto R, Sakagami RS, Saliba O. Infiltração marginal após o emprego do hidróxido de cálcio como curativo de demora. Rev Odont UNESP 1993;22:249-255.

18. Ho CH, Khoo A, Tan R, Teh J, Lim KC, Sae-Lim V. pH changes in root dentin after intracanal placement of improved calcium hydroxide containing gutta-percha points. J Endodon 2003;29:48

19. Holland GR. Leakage around root canal fillings. Int Endod J 1993;26:15.

20. Kersten HW, Moorer WR. Particles and molecules in endodontic leakage. Int Endod J 1989;22:118-124.

Accepted March 31, 2003 